\title{
Pyridoxine-refractory congenital sideroblastic anaemia with evidence for autosomal inheritance: exclusion of linkage to ALAS2 at Xp11.21 by polymorphism analysis
}

\author{
P E Jardine, P D Cotter, S A Johnson, E J Fitzsimons, L Tyfield, P W Lunt, \\ D F Bishop
}

\begin{abstract}
A son and daughter of unaffected parents had transfusion dependent, pyridoxinerefractory sideroblastic anaemia from birth. Their haemoglobin levels were $4 \cdot 3$ and $6.4 \mathrm{~g} / \mathrm{dl}$, respectively. $\delta$-Aminolaevulinate synthase activity in erythroblasts from fractionated marrow of the sister was $135 \mathrm{pmol} \delta$-aminolaevulinate formed $/ 10^{6}$ erythroblasts/hour (normal range $=110-650 \mathrm{pmol})$. While mutations of the erythroid-specific $\delta$-aminolaevulinate synthase gene (ALAS2) at Xp11.21 have been reported in patients with $X$ linked sideroblastic anaemia, sequence analysis of the ALAS2 gene in the son did not identify any mutations in the coding region, the intron/exon boundaries, or the $1 \mathrm{~kb} 5^{\prime}$ promoter region. A useful polymorphism was found in the $3^{\prime}$ region of the ALAS2 gene, a $G$ to $A$ transition, 220 nt 3' of the AATAAA polyadenylation signal. Mismatch PCR at this site and subsequent discrimination by $\mathrm{XmnI}$ restriction analysis of 148 alleles identified the gene frequency of this polymorphism to be $25 \%$. Analysis of the inheritance of this intragenic polymorphism showed that the affected sibs received different maternal alleles at the ALAS2 locus, excluding mutations in this gene as the cause of their sideroblastic anaemia. Furthermore, the absence of a dimorphic erythrocyte population in the mother, coupled with the demonstration of random $X$ inactivation in her peripheral leucocytes, showed that the mother was not the carrier of any $X$ linked sideroblastic anaemia mutation. These results strongly suggest that the sideroblastic anaemia in this family is an autosomal recessive trait.
\end{abstract}

(f Med Genet 1994;31:213-218)

The sideroblastic anaemias are a heterogeneous group of disorders characterised by anaemia of varying severity, ineffective erythropoiesis, increased body iron stores, and the presence of ringed sideroblasts in the bone marrow. ${ }^{1}$ Sideroblastic anaemia occurs most frequently in the middle aged and elderly as an acquired defect sometimes associated with malignancy. It is also found secondary to certain drugs and toxins. ${ }^{1}$ More rarely, sideroblastic anaemia is inherited as an $\mathrm{X}$ linked disorder which may be pyridoxine-responsive or refractory. ${ }^{2}$ Carrier females may be identified by moderately lowered haemoglobin and the presence of a dimorphic blood film owing to a bimodal erythrocyte volume distribution. $\delta$-Aminolaevulinic acid synthase (ALAS: succinyl CoA:glycine $C$-succinyltransferase [decarboxylating]; EC 2.3.1.37) was a candidate gene ${ }^{3}$ for $\mathrm{X}$ linked sideroblastic anaemia (XLSA) since decreased ALAS enzymatic activity had been reported in the bone marrow of affected patients ${ }^{45}$ and treatment with pyridoxine, whose metabolite (pyridoxal 5'-phosphate) is the cofactor for ALAS, may result in clinical improvement. ${ }^{3}$ Two ALAS genes, one housekeeping and one erythroid-specific, have been isolated and characterised. ${ }^{67}$ The erythroid-specific gene for $\delta$-aminolaevulinate synthase (ALAS2) has been localised to the distal subregion of the chromosomal band Xp11.21. ${ }^{8}$ Recently, the prediction that ALAS could be a candidate gene for XLSA was substantiated by the identification of a point mutation in exon 9 of ALAS2 in a patient with XLSA. ${ }^{9}$ This index case was pyridoxine-responsive, as were additional XLSA patients with other mutations in ALAS2. ${ }^{11} 11$ There is also evidence that mutations at another locus on the $\mathrm{X}$ chromosome may cause sideroblastic anaemia. Raskind et $a l^{12}$ reported a kindred with XLSA and ataxia that showed linkage to phosphoglycerate kinase at Xq13. Similarly, structural rearrangements of the $\mathrm{X}$ chromosome with breakpoints at Xq13 have been described in acquired disorders with sideroblastic haemopoiesis. ${ }^{13}$

Inheritance of sideroblastic anaemia which was not X linked has been reported. Mitochondrial DNA deletions in Pearson syndrome result in sideroblastic anaemia with neutropenia, thrombocytopenia, pancreatic fibrosis, and vacuolisation in the bone marrow. ${ }^{14}{ }^{15} \mathrm{~A}$ very small number of patients have been identified with sideroblastic anaemia consistent with autosomal inheritance. ${ }^{1617}$ We describe such a brother and sister with pyridoxine-refractory, transfusion dependent, congenital sideroblastic anaemia which is not the result of mutations in the ALAS2 gene. 


\section{Case reports}

CASE 1

This male infant, born 12.6 .89 , the first child of healthy unrelated parents of English descent, was pale at birth. At 2 days of age there was respiratory distress, hepatosplenomegaly, and scrotal oedema. Investigation of the proband showed a hypochromic, microcytic anaemia (haemoglobin $4.3 \mathrm{~g} / \mathrm{dl}, \mathrm{MCV} 68 \mathrm{fl}$, platelets $241 \times 10^{9} / 1$, white cell count $\left.10.2 \times 10^{9} / 1\right)$. Haemoglobin electrophoresis was normal. The bone marrow was hyperplastic with many late normoblasts. Perls' stain showed increased storage iron with at least $60 \%$ ringed sideroblasts. No vacuolisation of erythroid or myeloid marrow precursors was observed. At 7 months of age pyridoxine therapy $(100 \mathrm{mg} /$ day orally) was started. There was no response to this nor to a subsequent three months' treatment with pyridoxal 5' phosphate $(100 \mathrm{mg} /$ day orally). Blood transfusions were required every five to six weeks from birth because of symptomatic anaemia. Iron chelation therapy (subcutaneous desferrioxamine) was started at 2 years of age. There was no clinical evidence of malabsorption. At the age of 3.5 years, growth and development were normal, pretransfusion haemoglobin was $6.5 \mathrm{~g} / \mathrm{dl}$ and serum ferritin $318 \mathrm{ng} / \mathrm{ml}$ (normal range 17-280). Haemoglobin and red cell indices were normal in both parents and a maternal grandmother and aunt, with no evidence of red cell dimorphism.

\section{CASE 2}

This younger sister of the proband, born 14.6.91, has followed a similar course to that of her brother. At birth there was pallor, oedema, and hepatosplenomegaly. Haemoglobin was $6.4 \mathrm{~g} / \mathrm{dl}, \mathrm{MCV} 62 \mathrm{fl}$, platelets $430 \times 10^{9} / \mathrm{l}$, and white cell count $12.1 \times 10^{9} / 1$. Blood transfusions were required every four weeks from birth. There was no response to three months' oral therapy with pyridoxine $(100 \mathrm{mg} /$ day) started at 1 month of age or three months' subsequent treatment with pyridoxal 5'-phosphate $(100 \mathrm{mg} /$ day $)$. The karyotype was $46, \mathrm{XX}$. Bone marrow aspiration at the age of 7 months, after six blood transfusions, showed scanty erythroblasts with marked sideroblastic features. At the age of 2.5 years, growth and development were normal. Pretransfusion haemoglobin was $6.0 \mathrm{~g} / \mathrm{dl}$ and serum ferritin $260 \mathrm{ng} / \mathrm{ml}$. Desferrioxamine treatment has not yet been started.

\section{Materials and methods}

\section{ERYTHROBLAST FRACTIONATION}

Bone marrow myeloid cells were lysed by a specific IgM monoclonal antibody (TG1). ${ }^{18}$ Remaining erythroblasts were fractionated using Percoll equilibrium density centrifugation ${ }^{19}$ to provide an erythroid fraction enriched for early and intermediate erythroblasts.

\section{ALAS ACTIVITY}

ALAS activity was assayed in whole and fractionated marrow by a radiochemical method using high performance liquid chromatography to isolate $\left[{ }^{14} \mathrm{C}\right]$-aminolaevulinic acid (ALA), as previously described. ${ }^{20}$ ALA utilisation was completely inhibited by $2 \mathrm{mmol} / 1$ EDTA and $0 \cdot 1 \mathrm{mmol} / 1$ succinyl acetone. Succinyl coenzyme A generation was provided by 0.5 units succinate thiokinase, $5 \mathrm{mmol} / \mathrm{l} \mathrm{GTP}$, $1.35 \mathrm{mmol} / 1$ coenzyme $A$, and $2 \mathrm{mmol} / 1$ $\mathrm{MgCl}_{2}$. Results were expressed as pmol ALA synthesised in one hour per $10^{6}$ erythroblasts.

\section{MUTATION ANALYSIS}

Screening for mutations in the $\mathrm{X}$ chromosomal ALAS2 gene was accomplished by sequence analysis as previously described. ${ }^{9}$ Genomic DNA was obtained from white cells of case 1 by phenol/chloroform extraction of EDTA blood using standard methods and all 11 exons, including the intron/exon boundary regions, $1 \mathrm{~kb}$ of sequence $5^{\prime}$ of the first exon, and 350 bp 3' of the last exon, were PCR amplified, subcloned into pGEM4Z (Promega) and sequenced. Oligonucleotides 5'-GCCGCCGAATTCACACCCCACCTGC-3' (sense) and 5'-GGATTTTTATTGAAACCATTGGAGAAGAAC-3' (antisense) were synthesised on a model 380B DNA Synthesiser (Applied Biosystems) as previously described ${ }^{9}$ and used to amplify a $353 \mathrm{nt}$ polymorphic fragment from the $3^{\prime}$ region of the ALAS2 gene. The antisense primer was designed for mismatch PCR, where the underlined nucleotide differed from the complement of the normal genomic sequence (...AGC- $\left.3^{\prime}\right)$. The resultant PCR product from the $\overline{\mathrm{D} N A}$ of case 1 contained an $X m n I$ site, whereas DNA from most normal subjects did not. Mismatch PCR was performed on 148 alleles from 81 unrelated subjects (67 females and 14 males). Each amplification reaction contained $1 \mu \mathrm{g}$ of genomic DNA, $100 \mathrm{pmol}$ of each primer, $50 \mu \mathrm{mol} / 1$ each dNTP, $50 \mathrm{mmol} / 1 \mathrm{KCl}, 10 \mathrm{mmol} / 1 \mathrm{Tris}-$ $\mathrm{HCl}, \mathrm{pH} 9 \cdot 0,0.1 \%$ Triton $\mathrm{X}-100,1.5 \mathrm{mmol} / 1$ $\mathrm{MgCl}_{2}$, and $2.5 \mathrm{U} \mathrm{Taq}$ polymerase (Promega) in a $100 \mu \mathrm{l}$ reaction volume. Conditions were $94^{\circ} \mathrm{C}$ for four minutes, then 30 cycles of $94^{\circ} \mathrm{C}$ for 30 seconds, $62^{\circ} \mathrm{C}$ for 30 seconds, and $72^{\circ} \mathrm{C}$ for one minute. PCR products were digested with $X m n I$ (New England Biolabs), electrophoresed in a $1.5 \%$ agarose gel, and visualised under UV light after ethidium bromide staining.

\section{$\mathrm{X}$ INACTIVATION ANALYSIS}

DNA was extracted from peripheral leucocytes of both patients and their parents, double digested with the restriction enzymes Pst $\mathrm{I}$ MspI and Pst I/HpaII ${ }^{21}$ and the DNA fragments separated by electrophoresis in $0.8 \%$ agarose. Fragments were blotted onto nylon membranes (Hybond N, Amersham Ltd) by capillary transfer and the membranes hybridised with the probe $M 27 \beta^{22}$ which had been radiolabelled with $\left[{ }^{32} \mathrm{P}\right] \mathrm{dCTP}$ by the random priming extension method (Amersham). 
G A $\quad$ T $\quad$ C

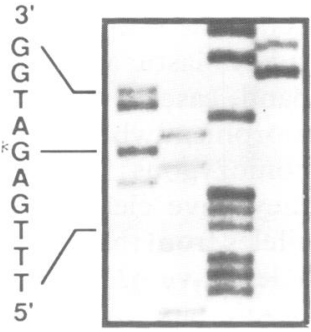

Normal
G A $\quad$ T C

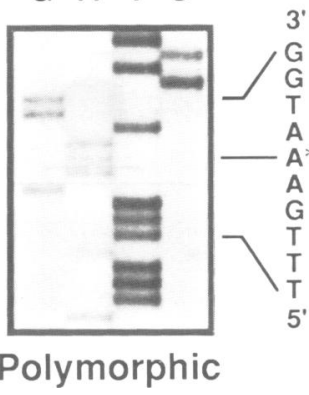

Figure 1 Sequence comparison of the normal and polymorphic alleles from the $3^{\prime}$ region of the $A L A S 2$ gene. The $G$ to $A$ transition identified in case 1 is indicated by asterisks. For additional details see Materials and methods

\section{Results}

ALA SYNTHASE ANALYSES

Measurement of bone marrow ALAS enzymatic activity was carried out to assess the possible involvement of this enzyme in the pathogenesis of sideroblastic anaemia in this family. ALAS activity in unfractionated marrow from case 2 was somewhat reduced at 370 pmol ALA formed $/ 10^{6}$ erythroblasts/hour (normal range 500-1200). Enzyme activity in the erythroblast fraction was 135 pmol ALA formed $/ 10^{6}$ erythroblasts/hour, in the low end of the normal range (110-650).

Sequence analysis of the ALAS2 gene showed that the genomic DNA from case 1 carried no mutation within any exon, within the intron-exon boundaries, or within $1 \mathrm{~kb}$ of sequence $5^{\prime}$ to exon 1 . However, a single nucleotide change (a $\mathrm{G}$ to A transition) (fig 1) was identified in the $3^{\prime}$ region of the gene, 220 nucleotides $3^{\prime}$ of the AATAAA polyadenylation signal. To identify this mutation easily, a synthetic mismatch PCR primer was constructed such that this nucleotide change would result in the creation of an $X m n I$ restriction site in the PCR product (fig 2). XmnI

A

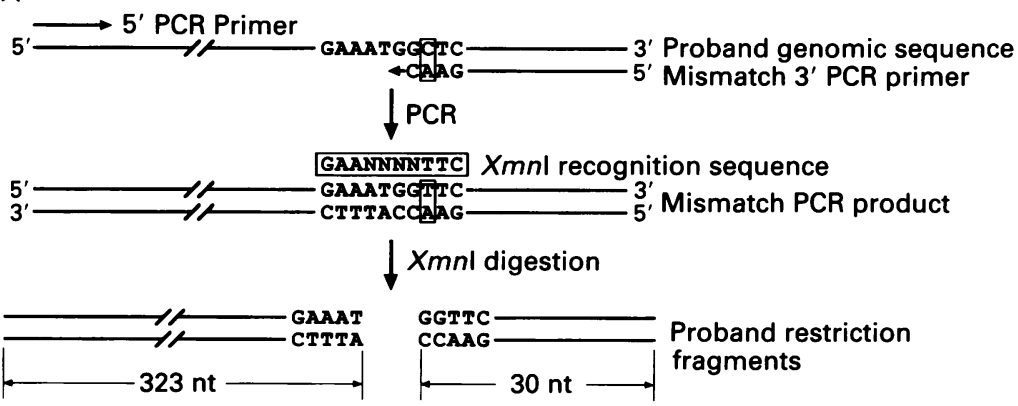

B

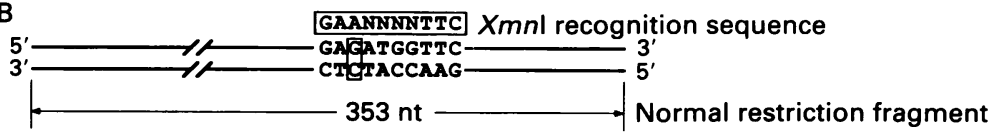

Figure 2 Mismatch PCR strategy for identification of the ALAS2 3 ' polymorphism. In panel $A, P C R$ amplification of genomic DNA using the $3^{\prime}$ primer containing the synthetic mismatch (boxed) yields a mismatch PCR product that contains an XmnI restriction site for subjects with the $G$ to $A$ transition. Subsequent restriction with

$X m n I$ shows presence of the polymorphism by production of $323 \mathrm{nt}$ and $30 \mathrm{nt}$

fragments. In panel $B$, when DNA is PCR amplified from subjects with the wild type $G \mathrm{nt}$ (boxed) the XmnI restriction site is not present and the $353 \mathrm{nt} P C R$ fragment is refractory to digestion. digestion of the mutant product generated fragments of 323 and 30 nucleotides, while the normal uncut product was $353 \mathrm{nt}$. Screening 148 alleles from 81 unrelated subjects (67 females and 14 males) by mismatch PCR and $X m n I$ digestion identified 111 alleles with the wild type nucleotide $G$, and 37 alleles with the mutation phenotype, indicating that the nucleotide change was a polymorphism with a frequency of $25 \%$. Screening the patients' family for the $X m n I$ polymorphism confirmed that case 1 was $X m n I$ positive and showed that the father and affected daughter (case 2) were $X m n I$ negative while the mother was heterozygous (fig 3). Thus ALAS2 mutations were confirmed not to be the cause of $\mathrm{X}$ linked sideroblastic anaemia in this family since the affected sibs inherited different ALAS2 alleles from the unaffected mother.

\section{METHYLATION PATTERN ANALYSIS}

If the proband's mutation was $\mathrm{X}$ linked one would have expected to see a dimorphic blood film in the mother, unless Lyonisation was non-random. Since the mother's blood film was normal, a methylation analysis was carried out to assess Lyonisation status. Methylation analysis of leucocyte DNA was conducted with the polymorphic probe $M 27 \beta$ as shown in fig 4 . Lanes $1,3,5$, and 7 were $P s t \mathrm{I} / M s p \mathrm{I}$ digests and lanes 2, 4, 6, and 8 were Pst I/HpaII digests. Using the methylation-insensitive MspI, the mother (lane 3) was clearly heterozygous (alleles 1 and 2) and the father (lane 1) was hemizygous for a smaller fragment (allele 3). At this locus the affected son and daughter (lanes 5 and 7) have inherited opposite alleles from their mother (alleles 2 and 1, respectively). Using the methylation-sensitive $H p a I I$,

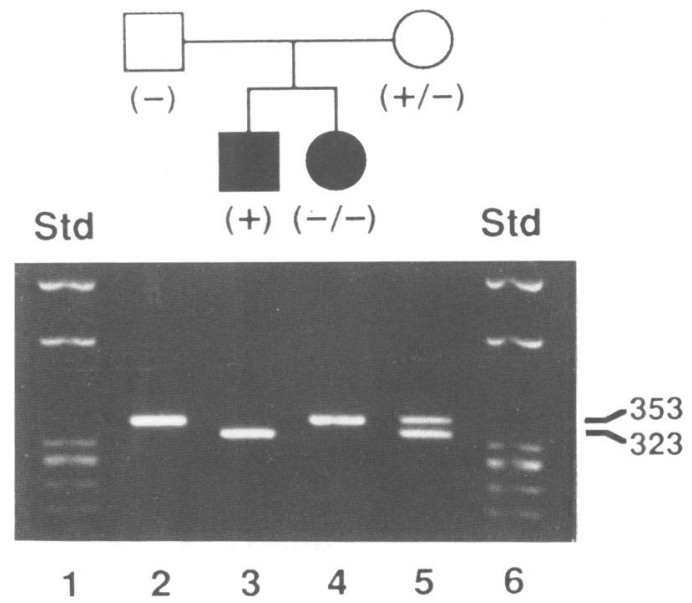

Figure $3 X m n I$ digestion of $P^{\prime} C R$ products from the $3^{\prime}$ region of the ALAS2 gene in members of the patients' family. Lanes 1 and 6 are the size standards generated by HaeIII digestion of $\varphi X 174$. Lanes 2 to 5 contain XmnI digested PCR products from the father, case 1 , his sister, case 2, and the mother, respectively. The wild type allele remains as a 353 nt PCR fragment after XmnI digestion ( -), whereas the polymorphic allele (the $G$ to $A$ transition) is cut into 30 nt (not seen here) and $323 \mathrm{nt}$ fragments ( + ). The father (lane 2) and daughter, case 2, (lane 4) were both XmnI negative, $(-)$ and $(-1-)$, respectively. The proband (lane 2) was XmnI positive ( + ) and the mother (lane 5) was heterozygous $(+1-)$. The two sibs have inherited different maternal ALAS2 alleles. 


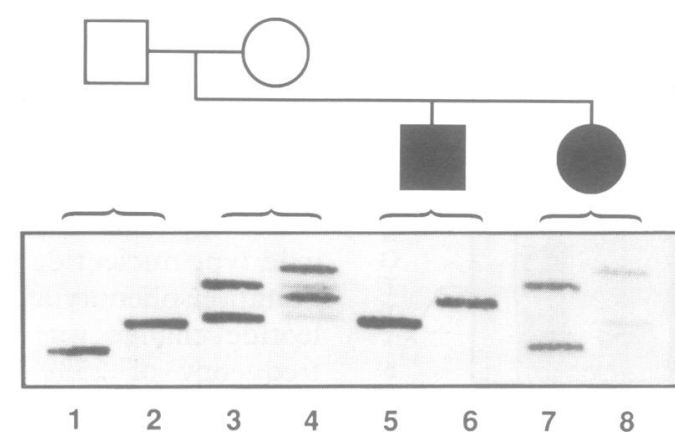

Figure 4 Methylation analysis of the proband, his sister, and parents using the polymorphic probe $M 27 \beta$. Lanes 1 and 2 are the father, lanes 3 and 4 the mother, lanes 5 and 6 case 1 , and lanes 7 and 8 his sister, case 2 . Lanes 1, 3, 5, and 7 were PstI/MspI digests and lanes 2, 4, 6, and 8 were PstI/HpaII digests. The Southern hybridisation analysis was performed as described in Materials and methods

the active, methylated $\mathrm{X}$ chromosome from the proband (lane 6) and his father (lane 2) was uncut at the $M s p I$ sites identified in lanes 1 and 5. Two darker bands corresponding to methylated alleles 1 and 2 and two lighter bands corresponding to unmethylated alleles 1 and 2 were visible in the mother's DNA (lane 4). This excess of methylated over unmethylated alleles in peripheral leucocytes has been shown previously; while all of the active $\mathrm{X}$ allele is methylated at the CCGG site, up to $60 \%$ of the inactive $\mathrm{X}$ allele can also be methylated. ${ }^{23}$ Thus, though reduced in intensity, the ratio of the HpaII cut (lower) bands provides an accurate estimation of the ratio of the inactive alleles. From the $H p a I I$ cut bands in fig 4, lane 4, the mother's DNA showed approximately $50 / 50$ random $X$ inactivation. Since the mother's blood smear was not dimorphic and Lyonisation was not severely skewed, this result extends the exclusion of ALAS2 as a possible cause of sideroblastic anaemia in this family to exclusion of the $\mathrm{X}$ chromsome as the carrier of the mutation.

\section{Discussion}

The molecular events causing the various inherited sideroblastic anaemias are beginning to be defined. Recently, hypochromic, microcytic, pyridoxine-responsive $\mathrm{X}$ linked sideroblastic anaemia (XLSA) was shown to be caused by point mutations in the erythroidspecific ALAS2 gene. ${ }^{9-11}$ In addition, a macrocytic sideroblastic anaemia with vacuolised marrow precursor cells and pancreatic insuffiency was shown to be caused by mitochondrial DNA deletions. ${ }^{15}$ Since one of the family members studied in this report had somewhat reduced marrow erythroblast ALAS activity, the family was evaluated for mutations in the ALAS2 gene.

The ALAS2 gene of the proband was normal by sequence analysis of the coding region, intron-exon junctions, and $5^{\prime}$ and $3^{\prime}$ flanking regions. This provided evidence for autosomal inheritance since mutations within this locus are the only described molecular defects in XLSA. ${ }^{9-11}$ The discovery of an informative polymorphic nucleotide change in the $3^{\prime}$ end of the ALAS2 gene enabled conclusive demon- stration that the erythroid-specific ALAS2 gene was not involved in the pathogenesis of sideroblastic anaemia in this family. The proband, case 1 , was positive for the $X m n I$ polymorphism while his affected sister, case 2 , was homozygous for the wild type allele. Thus, they have clearly inherited different ALAS2 alleles from their unaffected mother, ruling out a defective ALAS2 gene as the cause of sideroblastic anaemia in this family. The slight reduction in ALAS activity observed in case 2 may be a secondary consequence of iron overload in the mitochondria.

In addition to XLSA caused by ALAS2 mutations, carrier females for $\mathrm{X}$ linked sideroblastic anaemia associated with ataxia also have a dimorphic erythrocyte population. ${ }^{1024}$ Methylation studies were undertaken to determine whether the expression of sideroblastic anaemia in this family could be explained by the presence of some other $\mathrm{X}$ linked gene and the non-random inactivation of the normal $\mathrm{X}$ chromosome. The polymorphic probe M27 $\beta$ and MspI digestion is highly informative with greater than $90 \%$ heterozygosity in females. ${ }^{25}$ Unlike the unmethylated $\mathrm{CpG}$ rich islands 5 of active housekeeping genes, certain $M s p I$ sites in the $M 27 \beta$ region are methylated on the active chromosome and unmethylated on the inactive chromosome. ${ }^{26}$ These sites occur within the extensively methylated $5^{\prime}$ region of a LINE-1 repetitive element at the DXS255 locus. ${ }^{27}$ The $\mathrm{X}$ inactivation status of alleles may be determined after digestion with the methylation-sensitive restriction enzyme HpaII. Although $\mathrm{X}$ inactivation status was evaluated in the patients' leucocytes rather than erythroblasts, previous studies have shown that both erythroid and myeloid cells have the same isozyme ratios for $\mathrm{X}$ linked genes. ${ }^{28}$ After $\mathrm{HpaII}$ digestion, it was clear that the mother's $\mathrm{X}$ chromosomes were randomly inactivated as judged by the appearance of two HpaII cut bands with an intensity ratio of approximately 50/50. Since the mother's blood film did not show a dimorphic distribution and the methylation study identified random $\mathrm{X}$ inactivation, the sideroblastic anaemia in this family was apparently not $\mathrm{X}$ linked. Interestingly, the DXS255 locus, detected by the $M 27 \beta$ probe, maps to $\mathrm{Xp} 11.22$, just distal to the ALAS2 locus at Xp11.21. ${ }^{829}$ Although the recombination frequency between DXS255 and ALAS2 is not known, the different genotypes of $M 27 \beta$ for case 1 versus 2 are consistent with inheritance of different ALAS2 alleles.

This is only the second case of pyridoxinerefractory congenital sideroblastic anaemia that is clearly autosomal recessive. The first case was the result of an autosomal pyridoxal kinase defect. ${ }^{30}$ However, this was apparently not the cause of sideroblastic anaemia in the present family as neither sib responded to pyridoxal 5'-phosphate therapy. Potentially, an autosomal gene involved in iron metabolism or in regulation of ALAS2 activity could contribute to the pathogenesis of sideroblastic anaemia in this family.

While there have been a few additional cases 
with features consistent with autosomal inheritance, ${ }^{161730-40}$ the only two families in which the mode of inheritance was well documented were two autosomal dominant cases. Amos et $a l^{17}$ showed transmission from father to son and van Waveren Hogervorst et $a l^{16}$ described a sideroblastic anaemia family with autosomal dominant inheritance of erythrocyte dimorphism. Published reports of females with congenital sideroblastic anaemia who presented during infancy or early childhood, suggestive of autosomal inheritance, are listed in the table. The case reported by Sansone et al ${ }^{39}$ described an affected girl of consanguineous parents in whom vacuolised marrow precursor cells were present. In Pearson syndrome the features of macrocytic anaemia, vacuolisation of the bone marrow precursors, neutropenia, and thrombocytopenia are the result of mitochondrial DNA (mtDNA).$^{14}$ Although there was normal endocrine pancreatic function, the case of Sansone $e t a l^{39}$ may represent a variant of Pearson syndrome. The involvement of a mtDNA deletion in the pathogenesis of the sideroblastic anaemia in the family reported here was unlikely as neither of the affected members had any of the clinical features associated with Pearson syndrome. ${ }^{1415}$ Furthermore, PCR analysis of mtDNA from the sibs provided no evidence for a mtDNA deletion (data not shown).

Notably, where evaluated, all of the cases listed in the table were pyridoxine-refractory. In contrast, many cases have been reported of XLSA which are pyridoxine-responsive. ${ }^{41-43}$ The first published mutation of the ALAS2 gene in a patient with XLSA was a defect in exon 9 , the location of the putative pyridoxal 5 '-phosphate binding site. ${ }^{9}$ This patient was pyridoxine-responsive, as was the mutant enzyme expressed in vitro. In addition, other pyridoxine-responsive patients with XLSA have recently been shown to have mutations in ALAS2.$^{1011}$ The family reported here, in addition to all of the presumed cases of autosomal inheritance of sideroblastic anaemia (table), were pyridoxine-refractory. Thus, we suggest that in cases of pyridoxine-refractory sideroblastic anaemia autosomal recessive mutations should be considered.

The family we have described has a uniquely severe, pyridoxine-refractory, trans-

Female children with congenital sideroblastic anaemia*

\begin{tabular}{|c|c|c|c|c|c|c|}
\hline Reference & Age & $\begin{array}{l}\text { Pyridoxine- } \\
\text { responsive }\end{array}$ & $\begin{array}{l}H b \\
(g / d l)\end{array}$ & $\begin{array}{l}M C V \\
(p l)\end{array}$ & $\begin{array}{l}\text { Transfusion } \\
\text { dependent }\end{array}$ & $\begin{array}{l}\text { Affected } \\
\text { relatives }\end{array}$ \\
\hline $\begin{array}{l}31 \\
32 \\
33 \\
34 \\
34 \\
35 \\
36 \\
37 \\
38 \\
30 \\
39 \\
40\end{array}$ & $\begin{array}{c}7 \mathrm{y} \\
6 \mathrm{wk} \\
9 \mathrm{mth} \\
3 \mathrm{yr} \\
15 \mathrm{mth} \\
2 \mathrm{mth} \\
25 \mathrm{mth} \\
5 \frac{1}{2} \& 7 \mathrm{y} \\
2 \mathrm{mth} \\
5 \mathrm{wk} \\
2 \frac{1}{2} \mathrm{y} \\
20 \mathrm{mth}\end{array}$ & $\begin{array}{l}\text { No } \\
\text { No† } \\
\text { No } \\
\text { No } \\
\text { No } \\
\text { No } \\
\text { No } \\
\text { NR } \\
\text { Not } \\
\text { No§ } \\
\text { No } \\
\text { NR }\end{array}$ & $\begin{array}{l}8 \\
8 \cdot 8 \\
6 \cdot 8 \\
\mathrm{NR}_{+}^{+} \\
7 \cdot 0 \\
3 \cdot 7 \\
\mathrm{NR} \\
5 \cdot 1 \& 5 \cdot 5 \\
4 \cdot 0 \\
6 \cdot 1 \\
7 \\
7 \cdot 7\end{array}$ & $\begin{array}{l}52 \\
90 \cdot 7 \\
52 \\
\mathrm{NR} \\
\mathrm{NR} \\
75 \\
64 \cdot 5 \\
\mathrm{NR} \\
\mathrm{NR} \\
95 \\
82 \\
59\end{array}$ & $\begin{array}{l}\text { Yes } \\
\text { Yes } \\
\text { Yes } \\
\text { Yes } \\
\text { Yes } \\
\text { NR } \\
\text { Yes } \\
\text { NR } \\
\text { Yes } \\
\text { Yes } \\
\text { Yes } \\
\text { NR }\end{array}$ & $\begin{array}{l}\text { No } \\
\text { Brother } \\
\text { No } \\
\text { No } \\
\text { Mother } \\
\text { No } \\
\text { No } \\
\text { Brothers (2) } \\
\text { No } \\
\text { No } \\
\text { No } \\
\text { No }\end{array}$ \\
\hline
\end{tabular}

* Values listed are for the earliest age at which the most complete data were reported. + Refractory to oral pyridoxal $5^{\prime}$-phosphate treatment only, pyridoxine responsiveness not reported.

$\ddagger$ Not reported.

$\S$ Unresponsive to pyridoxine but responsive to pyridoxal $5^{\prime}$-phosphate.

| Consanguineous parents. fusion dependent disorder that is not the result of a mutation in the ALAS2 gene. The exclusion of ALAS2 in the disease pathogenesis, the evidence against other forms of $\mathrm{X}$ linked sideroblastic anaemia by methylation analysis, and the absence of any haematological manifestations in the parents strongly suggest that the sideroblastic anaemia in this family is caused by an autosomal recessive gene. Proof of this awaits identification of the mutation causing sideroblastic anaemia in this family. In addition, the availability of an informative ALAS2 polymorphism, which can be easily detected by mismatch PCR and XmnI digestion, and the recently described intron 7 polymorphism, ${ }^{44}$ will be useful in additional studies of ALAS2 and sideroblastic anaemia.

We would like to thank Dr T J French, Musgrove Park Hospital for permission to report the family. This study was supported in part by a grant (R01 DK40895) to DFB from the National Institutes of Health. PDC is the recipient of a March of Dimes Predoctoral Graduate Research Training Fellowship. PEJ is funded by the Research Committee of the South Western Regional Health Authority.

1 Bottomley SS. Sideroblastic anaemia. Clin Haematol 1982;11:389-409.

2 Losowsky MS, Hall R. Hereditary sideroblastic anaemia. Br f Haematol 1965;11:70-85.

3 Aoki Y, Urata G, Wada O, Takaku F. Measurement of $\delta$ aminolevulinic acid synthetase activity in human erythroblasts. $\mathcal{f}$ Clin Invest 1974;53:1326-34.

4 Takaku F, Nakao K. $\delta$-Aminolevulinic acid synthetase activity in erythroblasts of patients with sideroblastic anemia. Life Sci 1971;10:721-6.

5 Tanaka $M$, Ota $H$. A case of primary acquired sideroblastic anaemia with deficient $\delta$-aminolevulinic acid synthase activity in bone marrow erythroblasts. Tohoku $\mathcal{f} \operatorname{Exp} M e d$ 1972;106:199-206.

6 Bishop DF. Two different genes encode $\delta$-aminolevulinate synthase in humans: nucleotide sequences of $\mathrm{cDNAs}$ for the housekeeping and erythroid genes. Nucleic Acids Res 1990;18:7187-8.

7 Bawden MJ, Borthwick IA, Healy HM, Morris CP, May BK, Elliott WH. Sequence of human 5-aminolevulinate synthase cDNA. Nucleic Acids Res 1987;15:8563.

8 Cotter PD, Willard HF, Gorski JL, Bishop DF. Assignment of human erythroid $\delta$-aminolevulinate synthase (ALAS2) to a distal subregion of band Xp11.21 by PCR analysis of somatic cell hybrids containing $X$;autosome analysis of somatic cell hybrids containin

9 Cotter PD, Baumann M, Bishop DF. Enzymatic defect in 'X-linked' sideroblastic anemia: molecular evidence for erythroid $\delta$-aminolevulinate synthase deficiency. Proc Natl Acad Sci USA 1992;89:4028-32.

10 Cotter PD, Baumann M, Rucknagel DL, Fitzsimons EJ, May A, Bishop DF. Heterogeneity in X-linked sideroblastic anemia due to unique mutations in the erythroid $\delta$ aminolevulinic acid synthase gene. Am $\mathcal{f}$ Hum Genet 1992;51:A45.

11 Cox TC, Bottomley SS, Wiley JS, May BK. Erythroid 5aminolevulinate synthase deficiency due to a point mutation in a kindred with $\mathrm{X}$-linked sideroblastic anemia. Blood 1992;80:341 A

12 Raskind WH, Wijsman E, Pagon RA et al. X-linked sideroblastic anemia and ataxia: linkage to phosphoglycerate oblastic anemia and ataxia: linkage to phosphogly
kinase at Xq13. Am f Hum Genet $1991 ; 48: 335-41$.

13 Dewald GW, Brecher M, Travis LB, Stupca PJ. Twentysix patients with hematologic disorders and $X$ chromosome abnormalities. Frequent idic $(X)$ (q13) chromosomes some abnormalities. Frequent idic $(X)(\mathrm{q} 13)$ chromosomes
and $\mathrm{Xq13}$ anomalies associated with pathologic ringed sideroblasts. Cancer Genet Cytogenet 1989;42:173-85.

14 Pearson HA, Lobel JS, Kocoshis SA, et al. A new syndrome of refractory sideroblastic anemia with vacuolization of marrow precursors and exocrine pancreatic dysfunction. f Pediatr 1979;95:976-84.

15 Rötig A, Colonna M, Bonnefont JP, et al. Mitochondrial DNA deletion in Pearson's marrow/pancreas syndrome. Lancet 1989;i:902-3.

16 van Waveren Hogervorst GD, van Roermund HPC, Snijders PJ. Hereditary sideroblastic anaemia and auto(ism in a Dutch family. Eur $\mathcal{f}$ Haematol 1987;38:405-9.

17 Amos RJ, Miller ALC, Amess JAL. Autosomal inheritance of sideroblastic anaemia. Clin Lab Haematol 1988;10:34753.

18 Beverley PCL, Linch D, Delia D. Isolation of human haematopoietic progeniter cells using monoclonal antihodies. Nature 1980;287:332-3.

19 Fitzsimons EJ, May A, Elder GH, Jacobs A. 5-Aminolaevulinic acid synthase activity in developing human eryth-

20 Fitzsimons EJ, May A, Elder GH, Jacobs A. Measurement 
of 5-aminolevulinic acid synthase activity in whole and fractionated human bone marrow: effect of myeloid cell lysis by monoclonal antibody. Anal Biochem 1986;153:917 .

21 Abrahamson G, Fraser NJ, Boyd Y, Craig I, Wainscoat JS A highly informative $X$-chromosome probe, M27 $\beta$, can be used for the determination of tumour clonality. $\mathrm{Br} \mathcal{F}$ Haematol 1990;74:371-2.

22 Fraser NJ, Boyd Y, Brownlee GG, Craig IW. Multi-allelic RFLP for M27 $\beta$, an anonymous single copy genomi clone at Xp11.3-Xcen [HGM9 provisional no. DXS255] Nucleic Acids Res 1987;15:9616.

23 Hendriks RW, Kraakman MEM, Mensink RGJ, Schuurman RKB. Differential methylation at the $5^{\prime}$ and the $3^{\prime}$ CCGG sites flanking the $X$ chromosomal hypervariable DXS255 locus. Hum Genet 1991;88:105-11.

24. Pagon RA, Bird TD, Detter JC, Pierce I. Hereditary siderboblastic anaemia and ataxia: an X linked recessive disorder. $\mathcal{f}$ Med Genet 1985;22:267-73.

25 Goodship J, Carter J, Espanol T, Boyd Y, Malcolm S, Levinsky RJ. Carrier detection in Wiskott-Aldrich syndrome: combined use of $M 27 \beta$ for $X$-inactivation studies and as a linked probe. Blood 1991;77:2677-81.

26 Boyd Y, Fraser NJ. Methylation patterns at the hypervariable X-chromosome locus DXS255 (M27ß): correlation able X-chromosome locus DXS255 (M27 $\beta$ ): correlation

27 Hendriks RW, Hinds $H$, Chen ZY, Craig IW. The hypervariable DXS255 locus contains a LINE-1 repetitive element with a CpG island that is extensively methylated only on the active X chromosome. Genomics 1992;14:598603.

28 Fialkow PJ. Primordial cell pool size and lineage relationships of five human cell types. Ann Hum Genet 1973;37:39-48.

29 Greer WL, Peacocke M, Siminovitch KA. The WiskottAldrich syndrome: refinement of the localization on $\mathrm{XP}_{\mathrm{P}}$ and identification of another closely linked marker locus, OATL1. Hum Genet 1992;88:453-6.

30 Ritchey AK, Wolfson S, Pearson HA Congenital sideroblastic anemia (CSA) responsive to pyridoxal-5-phosphate. Pediatr Res 1980;14:538.
31 Agarwal MB. Congenital sideroblastic anemia in a female. Indian Pediatr 1988;25:685-8.

32 Andersen K, Kaad PH. Congenital sideroblastic anaemia with intrauterine symptoms and early lethal outcome. Acta Paediatr (Scand) 1992;81:652-3.

33 Buchanan GR, Bottomley SS, Nitschke R. Bone marrow delta-aminolaevulinate synthase deficiency in a female with congenital sideroblastic anemia. Blood 1980;55:10915.

34 Dolan G, Reid MM, Congenital sideroblastic anaemia in two girls. $\mathcal{F}$ Clin Pathol 1991;44:464-5.

35 Hamel BCJ, Schretlen EDAM. Sideroblastic anaemia. A review of seven paediatric cases. Eur $\exists$ Pediat 1982;138:130-5.

36 Hilton HB. Congenital siderocytic hypochromic aplastic anaemia. Proc $R$ Soc Med 1959;52:641-2.

37 Kasturi J, Basha HM, Smeda SH, Swehli M. Hereditary sideroblastic anaemia in 4 siblings of a Libyan family autosomal inheritance. Acta Haematol 1982;68:321-4.

38 Manabe Y, Seto S, Furusho K, Aoki Y. A study of a female with congenital sideroblastic anemia. Am $\mathcal{f}$ Hematol with congeniti:

39 Sansone G, Masera G, Terzoli S, Cantù-Rajnoldi A. Congenital refractory anaemia with vacuolisation of bone marrow precursors, sideroblastosis and growth failure in marrow precursors, sideroblastosis and growth failure in a girl with normal endocrin

40 Seip M, Gjessing LR, Lie SO. Congenital sideroblastic anaemia in a girl. Scand $\mathcal{F}$ Haematol 1971;8:505-12.

41 Horrigan DL, Harris JW. Pyridoxine-responsive anemia: analysis of 62 cases. Adv Intern Med 1964;12:103-74.

42 Bourne MS, Elves MW, Israëls MCG. Familial pyridox ine-responsive anaemia. $B r \mathcal{F}$ Haematol 1965;11:1-10. 43 Holmes J, May A, Geddes D, Jacobs A. A family study of
congenital X linked sideroblastic anaemia. $\mathcal{F}$ Med Genet 1990;27:26-8.

44 Cox TC, Kozman HM, Raskind WH, May BK, Mulley JC. Identification of a highly polymorphic marker within intron 7 of the ALAS2 gene and suggestion of at least two loci for X-linked sideroblastic anemia. Hum Mol Genet 1992;1:639-41. 